\title{
Heterogeneity as the Source of the State's Resilience: The Case of Spatial Planning under State-Led Neoliberalization in South Korea
}

Jung Won Sonn and Dongheon Lee

\begin{abstract}
Existing theories on the state and neoliberalism demonstrate that the state is resilient enough to restructure itself under neoliberalization of the economy. These theories, however, do not explain exactly how and why the state can be resilient. Using the case of spatial planning in South Korea around the turn of the millennium, when neoliberalism was an apparent consensus and the economy clearly was neoliberalized, this paper attempts to demonstrate that the source of the state's resilience is the heterogeneity of the neoliberal consensus. Neoliberalism, as a geographically and historically specific ideology in South Korea, combines political liberalism, economic conservatism, resistant regionalism, and localism. This heterogeneity within the neoliberal consensus in the ruling block allows the state to interpret neoliberalism in such a way that it can maintain a strong hold on its spatial economy by combining various spatial planning measures and simultaneously adjusting its spatial economy to accord with the neoliberalization of the global economy.
\end{abstract}

KEY WORDS: neoliberalism, state theory, South Korea, developmental state, regional planning

\section{Introduction}

Neoliberalism is, at least in its pure ideological form, among other things, the preference for market over state intervention (Saad-Filho and Johnston, 2005). As such, it was often assumed that neoliberalization equals a weakening of the state's role in the economy. Recent findings, however, show that the state is often an active agent in, rather than a helpless victim of, neoliberalism (Peck and Tickell, 1994). Within the discussion of the state's spatial dimension, political geographers and political scientists have shown that the state actively allocated its earlier rights and duties to local governments. Thus, the state's restructuring is a change in the spatiality of the statehood, rather than a weakening of the state (Brenner, 2004). These authors, however, do not explain exactly why and how the state possesses such resilience. 
Using the South Korean experience in the early 2000s, when neoliberalism was a consensus in South Korea, this paper shows that the state can use neoliberal discourse to strengthen rather than weaken itself. More specifically, this paper looks at the state's spatial strategies and show that it could use two opposite strategies, which we call containment and diffusion, to better adapt its national economy to globalization while simultaneously reinforcing its hold on the spatial economy within its territory. This paper further argues that the heterogeneous mix of ideologies within the hegemonic block allows the state to combine those ideologies in interpreting a fragile consensus in such a way that the state strengthens itself.

\section{Theorizing Neoliberalization and the State}

Mainstream globalization research assumes that the national state's power has been substantially weakened by the increasing mobility of capital. Globalization theorists ascribe the weakening of state power to the telecommunication revolution (Wriston, 1992) or to the deregulation rally, in which states were forced into competing with one another (Cerny, 1995; Sinclair, 1994), or to both (Strange, 1996). (See also Giddens, 1990; Gray, 1998; Greider, 1997; Hardt and Negri, 2000; Lash and Urry, 1994; Swyngedouw, 1997). Thus, such research concludes that neoliberalization is a forced response from the national state that dismantles the state itself. If one takes this theoretical position, analysis of neither the national state nor its policies would prove very useful. If the state's actions are determined by global forces, such forces should be the focus in state analyses.

More recently, however, the emerging consensus is that the depiction of the state as a helpless victim is, at best, exaggerated. Among the various theoretical strands that find that the state plays an active role in the neoliberal global economy, two groups of theories are prominent: the Weberian theory of the state and the Marxist theory of the state. These alternative theories can describe the resilient nature of the state in the context of neoliberal globalization. These theories, however, do not give a full explanation of where this resilience comes from.

\section{Weberian Approaches}

Linda Weiss and Robert Wade argue that globalization theory is an exaggeration of reality. According to them, globalization theorists overestimate the capacity of the state from earlier times and underestimate the capacity of the state in current times. In reality, the state has always had trouble controlling international finance, even before the 20th century. Many nation-states, particularly those in East Asia, have been successful in 
adapting to, and even coordinating, the globalization of capital (Weiss, 1998; Wade, 1996).

Linda Weiss attempts to overcome what she calls the "globalization theory," which regards the state as a mere victim of the global economy. She seems to develop interlinked but separate explanations of the state's livelihood on two spatial scales. On a global scale, she argues that the relationship between state sovereignty and global economic integration is not a zero sum game but rather a mutual reinforcement. Because the nation-states are "important drivers" and "normative and organizational supports" for globalization, contemporary globalization is a national process as much as it is a global process (Weiss, 2005: 352).

On a national scale, Weiss demonstrates through East Asian cases that the state still possesses great leverage in controlling international financial flow. She does acknowledge that globalization creates constraints for some policy areas, but she also emphasizes that there is "ample room for action in key policy areas" (Weiss, 2005: 345). Because mobility is increased, the state incentives "take initiatives that will strengthen the national system of innovation and social protection" (Weiss, 2003:15). Based on this reasoning, she claims that globalization has an "enabling face" or "augmenting effects", as well as a constraining aspect.

The merit of Weiss's approach is that, according to her framework, financial neoliberalization can coexist with a strengthening of the welfare regime. Because she sees the "enabling face" as coexistent with global constraints, she can ascribe contradictory factors to one or the other. Furthermore, her approach helps us recognize that the state is an active participant, a gatekeeper, and a filtering agent, rather than a mere victim, of the neoliberalization process.

However, the weakness in her framework is that the realization of the "enabling face" is completely dependent on the choices of elites choice. She accepts that the "enabling face" exists only potentially and thus that its realization is dependent on historical contingencies. She explains why the state needs to play more important roles under globalization, but falls short of elaborating upon whether the state can or will.

She cites Peter Katzenstein's (1985) case studies and claims,

The greater the level of (trade) interdependence, the stronger the elite perception of vulnerability, and the greater the likelihood of compensatory and inclusionary domestic structures which blunt rather than exacerbate the pressure of openness ( $\mathrm{p}$. 14).

However, this is again only a description of the need. It is still not clear whether the elites will respond to the needs of the people. She seems to attempt to argue that globalization's "enabling face" is realized when there is enough of a "voice" from the 
people (Weiss, 2005: 347), but she stops there. She does not explain under what circumstances the "voice" can get stronger, and under which circumstances the state will respond to that "voice." The "voice" does not automatically arise even if the oppressed class needs it to express their frustrations. This is because there are elaborate mechanisms in place to tame the voices of the oppressed, as considered in the Gramscian discussion on hegemony and the more recent Foucauldian discussion on governmentality (Sonn and Gimm, 2013). Furthermore, even if people actually raise their voices, the elites do not necessarily respond. In fact, labor is less mobile than capital, so elites may want to take the exit of capital more seriously than the voice of the people.

\section{Marxist Approaches}

Like Weberians, those who are related to regulation theory in its wider definition argue that the state's incompetence is exaggerated. Regulationists accept that globalization creates constraints on the state's capacity to manage its economy:

The growing internationalization of capital accompanying the final stages of Fordism transformed the situation: wages were increasingly seen primarily as a cost of production and only secondarily as a source of national demand. This holds for both individual wages and the social wage. This threatened the national institutionalized class compromise between organized labour and domestic industrial capital and, in conjunction with the inversion of the primary and secondary aspects of the money form, tends to shift the balance of power in this compromise from organized labour to productive capital (Jessop, 2002: 105).

As a result, the state is now labeled a Schumpeterian competition state, which, among other things, "chang[es] regulatory frameworks to facilitate labor-market flexibility and mobility within the national economic space," "engag[es] in complementary forms of Standortpolitik and other forms of place-based competition in an attempt to fix mobile capital within the state's own economic spaces and to enhance the interurban, interregional or international competitiveness of its own place-bound capitals" (p. 138), and "socializ[es] long-term conditions of production as short-term calculation becomes more dominant in marketized economic activities" (p. 139).

However, the acceptance of an increasingly difficult situation for the state does not equate to the admission of the state's total incompetence. As Weiss does, Jessop claims that the state still has substantial power to influence its domestic political economy and its inbound and outbound flow of capital, despite the increasing transnational mobility of capital. 
Localization is often regarded as the self-dissolution of the nation-state. Jessop accepts that the scale of the national state is currently going through a "hollowing out" of sovereignty, giving out part of its sovereignty to transitional and local political units. However, Jessop, Brenner, and Jones see this hollowing out as the nation-state's choice rather than a forced response.

The state has strategic selectivity in place that favors certain economic sectors over others (Jessop, 1992). Geographically, the state strategically selects the scale of the city rather than the scale of the national state as a proactive strategy in accommodating, facilitating, and even promoting globalization (Jones, 1999).

State spatial restructuring is best viewed as a layering process in which newly emergent state spatial projects and state spatial strategies interact with the inherited configuration of state space. This interaction generates new, multilayered formations of state spatiality that eclectically combine elements of inherited state spatial arrangements with newly forged regulatory geographies (Brenner, 2004, p. 192).

Therefore, "neoliberalism must be viewed as a concerted political strategy through which qualitatively new forms of state-economy relations have been constructed, at various spatial scales," (Brenner, 2004: 200) for the elimination of the post-war welfare regime that is now viewed as a cost that only hinders international competitiveness, rather than as a source for domestic demand. Again, like Weberians, the Marxist approach does not explain from where this resilience of the state comes.

\section{Heterogeneous Strategies in Neoliberal Spatial Policies in South Korea}

Since its democratization, which proceeded gradually between 1987 and 1997, South Korea's public policy has shown two distinctive features. In diverse areas of economic policy, the current South Korean state can be called neoliberal, without much opposition: The financial market very quickly opened up to the international flow of capital. In late 2005, the share of foreigners in the stock market in terms of total market value was $40.5 \%$, versus only $14.6 \%$ in late $1997 .{ }^{1}$ The share of foreign banks grew fivefold, and the share of foreign insurance companies in life insurance grew by a factor of 16 since the 1997 economic crisis. ${ }^{2}$ These are the results of policies by the Kim Dae

\footnotetext{
${ }^{1}$ ETNEWS 2005, December 12, www.etnews.co.kr/news/detail.html?id=200512120033 (Accessed February 19, 2006).

2 Hankyoreh 2005, December 26, www.hani.co.kr/kisa/section003001000/2005/12/003001000200512261833457.html (Accessed February 19, 2006).
} 
Jung and Roh Moo Hyun administrations. In the labor market evidence of neoliberalism is even clearer. In August 2004, 59.6\% of workers were in contingent employment of one form or another, leaving behind the legend of lifetime employment under the developmental state. In this regard, it is safe to say that South Korea's financial and labor policies since the 1997 economic crisis have been governed by a neoliberal ideology. ${ }^{3}$

Under the dominance of neoliberalism, however, state intervention in spatial planning did not decrease. What is more interesting than the quantity of the state intervention is the contradiction between its content and the delivery mechanism. As shown in the following sections, the content of spatial planning during these two administrations was, to a considerable degree, neoliberal. However, this content was combined with the traditional administrative mechanism of strong central government intervention. The state combines different spatial strategies for different policy contents so that it does not lose its control over economic activities within its territory. Two examples in which opposite spatial strategies were used are covered below; I call these strategies "containment" and "diffusion", respectively. Containment strategy is an approach whereby the neoliberal content of spatial policy is contained within the boundary set by the state. By contrast, diffusion strategy is an approach designed to spread neoliberal content to the entire territory.

\section{The Incheon Free-Economic Zone: Containment Strategy}

The containment strategy of neoliberal spatial policy is evident in the development of the Incheon Free Economic Zone, which is a full-fledged neoliberal space created by the national state. The Incheon Free Economic Zone is composed of three districts (Songdo, Cheongna, and Yeongjong) in 209 square kilometers, an area slightly bigger than Monaco. When development is completed as planned in 2020, the area will have 480,000 residents. The total public budget for infrastructure is $\$ 15$ billion (Incheon City Government and Ministries of the Knowledge Economy, 2007).

\footnotetext{
${ }^{3}$ In other areas, however, policies that are not compatible with, or sometimes contradictory to, neoliberalism can be found easily. One of the prominent examples is the government's welfare expenditure. The central government's welfare budget more than doubled in eight years, jumping from $0.8 \%$ of the GDP in 1997 to $1.7 \%$ in 2005 (Choi, 2005); 1.7\% is less than half of the OECD average, but as South Korea's population ages, the number of recipients of retirement benefits will grow, and the welfare budget to GDP ratio should approach the European level in 20 years, without introducing any new benefits. This fast growth, which is difficult to find in advanced capitalist countries, led some of the authors to conclude that South Korea's welfare regime is approaching the continental European model of social welfare (Kim, YM, p. 356). While there are debates about the nature of the welfare expenditure, the emerging consensus among experts on South Korean social policy is that this welfare growth is not explained by the trend of neoliberalization the South Korean state is following.
} 
The origin of the plan can be found within the local government. In the late 1980s, there were attempts among local government officials, with support from the local business community, to formulate ideas about the transformation of Incheon's economy from manufacturing to high-tech (Park, YS, 2008: 20-24). However, the local climate for this project quickly changed after President Roh Tae Woo (1988-1992) was elected. He promised, as a presidential candidate, to build 2,000,000 houses to ease the housing shortage nationwide, especially in the capital region. The business hub proponents within the Incheon government thought they could make a "superficial" change to the project by adding a little more housing and by packaging the whole project as a part of the president's housing policy. That way they could receive support from the central government. Now the project is called "Songdo New Town." The national government supported the project because Incheon is only 15 kilometers away from Seoul, where the housing shortage was not severe.

However, this "superficial" change created a more fundamental alteration to the project than originally intended. After housing became a more explicit part of the project, the majority of local elites, who up until that point had been quiet about the project, began to argue that housing is a better way for the development of Songdo to achieve success (Sonn, Shin, and Park, 2015).

During this period of confusion, South Korea was hit by the East Asian Economic Crisis in 1997. This national crisis gave Songdo national importance. The discourse about a free-economic zone (hereafter referred to as a "FEZ") had existed within the central government, but after the economic crisis hit it suddenly became a concrete policy agenda item. During the crisis, national competitiveness occupied the central position in policy discourse among academic and policy circles. Within that discourse, hosting multinational firms was regarded as the defining factor of national competitiveness. Under the sway of this discourse, it seemed only natural that Songdo would serve as a national project.

It was also natural that the discourse of deregulation would revolve around the labor, technology, industrial, and environmental policy areas. In such a discursive landscape, the regional balance policy that was curbing the growth of the capital region was seen as an obstacle to national economic growth because the capital region is the most competitive region in the country. As such, creating a free-economic zone in Incheon, which is within the capital region, was now an acceptable policy measure.

As Kim (2007) rightly pointed out, this project is being designed and implemented by the national state. The implementation of the project is maintained by the Committee for an Economic Special Zone under the central government's minister of finance and economy, according to the Law for Designation and Management of a Free Economic Zone.

President Kim Dae Jung announced the "Strategy for a Business Hub of Northeast Asia" in his New Year's Speech in 2002 (January 14, 2002). Under this plan and 
subsequent policy measures, Songdo as a FEZ would be a full-fledged neoliberal space plugged into the global circuit of capital. Later in that same year, the Ministry of Finance and Economy announced its strategic master plan, of which FEZ was an important part. Under this master plan, a business-friendly and residential environment suitable for highly skilled, highly paid foreign employees would have been provided. English would become an official language along with Korean, and the U.S. dollar and the Japanese yen would be official currencies along with the Korean won. The FEZ Authority would be set up and would provide a "one-stop service" for taxes, financing, and employment issues for investors (Shin, Sonn, and Park, forthcoming).

The dominance of the national state is reflected in the words of Stan Gale, the president of Gale Company:

We were invited in by the central government of Korea. ... The central government of Korea views this as a national project, and they teamed us up with Korea's leading corporation, Posco Engineering \& Construction Co. Ltd. ... We were able to get government buy-back guarantees on the land and all kinds of insurance (Wood, 2004, quoted in Kim (2007): 205-206, footnote 51).

The national state has created laws and other institutions for only this zone. The Law for the Designation and Management of a Free Economic Zone covers all FEZs, but it is intended mainly for the Incheon FEZ. In the Songdo FEZ, firms enjoy cuts in national and local taxes. The local governments are allowed to provide aid for the collective consumption of goods such as education, health care, housing, among others. It was also planned that all government documents would be published in English (Kim, 2007: 202). As has been made evident there, the project is certainly receiving special treatment from the national states. In that sense, the nation state's strategy is a spatially differentiating one (Ong, 2000).

The neoliberal contents of a free economic zone would certainly undermine the state's control of economic activity within that zone, thereby challenging the state's sovereignty. This is why the full-fledged neoliberalist practice had to be contained within the zone. At the time of the national economic crisis, foreign investment was necessary for economic and ideological reasons. An important cause of the crisis was the flight of foreign investment, so the state intended to bring such investment back. Foreign capital before the crisis was in the form of loans to Korean banks, so the state wanted direct investment. For that, a free economic zone could be useful. Foreign capital was also necessary for political reasons. Newly-elected Kim Dae Jung, who had been the leader of an anti-authoritarian movement, had to prove that he could competently handle the economy, and bringing in foreign capital would serve that purpose. However, a complete opening of the territory would cause the state to lose its control over economic activities, 
so the opening had to be spatially contained, and a free economic zone would serve that purpose.

\section{Regional Balance Policy: Diffusion Strategy}

The Roh Administration attempted to disperse economic activities to less developed parts of the country, but many of these earmarked funds were conditional upon the local governments' actions toward technological innovation and administrative reforms. The neoliberal character of the Roh Administration's regional balance reveals itself with the concept of "independent localization."

Independent localization is a strategy to enhance localities' creativity, proactiveness and dynamics based on devolution and self-determinacy. At the same time, it is [the Roh Administration's] main strategy for spatially-balanced development that aims at simultaneously achieving both regional development and national development (Nam, 2008): 44).... Independent localization is a shift of paradigm because it is an attempt to eradicate the old strategy of localization, which was [the local government's] competition in receiving the central government's aid. Independent localization promotes the development of a regional innovation system through networking among industry, education and research communities and pursues endogenous regional development through a regional innovation system (Nam, 2008: 45).

Funding from "Chiyok Hyoksin Saop Gaejong” (the Regional Innovation Projects Account) aimed to improve localities' growth-potential based on endogenous resources (Nam, 2008: 46). The requirements of this fund also resembled the descriptions of successful regional innovation systems. Organization of a "Regional Innovation Committee" was the first requirement, whereby local leaders of the business community, civil society, and academia should discuss an innovation-led local development strategy. In addition, to strengthen networks among industry, university, and public research institutes, the administration encouraged local research universities, local industryuniversity partnerships, and joint ventures among local industry, university, and public research institutes through the Connect Korea project (Nam, 2008: 115). ${ }^{4}$

\footnotetext{
${ }^{4}$ However, the neoliberal character of the Roh Administration's spatial policies should not be overstated. Like any other policies, the Roh Administration's spatial policies are constructed through political processes and do not directly reflect a pure ideology. Among the spatial strategies that the Roh Administration deployed, some are categorized as "Cohesion Policies" as stipulated by "Chiyok Gaebal Saop Gaejong (the Regional Development Project Account)." Under this project account, the national state's aid was given to underdeveloped regions and rural
} 
The main difference between the Roh Administration and previous administrations is not the total amount of expenditure on regional balance, which, in the forms of the local share of tax collection and central government's budget transfer and aid to the local, has been an increasing part of the national state's budget for quite some time. Rather, it is the requirements that the Roh Administration imposed on localities (Nam, 2008: 68).

The Five-Year Plan for Innovative Regional Development was another requirement that was imposed. By writing and implementing this plan, the local government became the main coordinator of universities and research institutes within its locality, although the allocation of $\mathrm{R} \& \mathrm{D}$ expenditures still comes from the central government.

It is noticeable that the innovative regional strategy is always backed up by the central government's support. R\&D expenditure and expenditure to local universities from the central government also increased under the NURI project. Other projects that involve the central government's support include Techno Park, the business incubator, the local IT center, and the local science park (Nam, 2008: 109).

There is a clear contradiction between the neoliberal contents of regional policies and the way those contents were delivered. While the policies' emphasis was on endogenous growth and the denial of paternalistic support for underdeveloped regions, the national state had strong control over those policies, using a strategy of carrots and sticks on local governments. The contents show that the national state succumbed to the neoliberal consensus both within and outside the country, but the delivery mechanism shows that the state tried not to lose control over its local governments. Rather than the spatial restructuring of statehood as occurred in West European countries, the South Korean state reconfirmed its original spatial configuration of state power by delivering the same contents that were combined with devolution in Western European countries.

\section{Neoliberalism as the Consensus among Heterogeneous Groups}

We claim that the combination of different strategies linking neoliberal ideology and the maintenance of a strong state was possible because of the heterogeneous character of the ruling block. That heterogeneity allowed the state to selectively utilize various interpretations of neoliberalism. In this section, we explore the heterogeneity of the ruling block.

In a Western context, "individual freedom" is a magic phrase used to justify neoliberalism. On the other hand, in South Korea, "democracy" has been the magic word.

areas. The state, however, warns that "cohesion policies" should be used with caution because too many will make localities dependent on the national state (Nam, 2008: 46). 
Because Hayek's concept of "freedom" encompasses many potentially contradictory factors, the factors included in the Korean concept of "democracy" are contradictory as well.

The two recent administrations' main legitimating discourse was democratization. While the current administration emphasizes "reform" instead of democratization, this change was mainly rhetorical: The current administration and its supporters use "reform" as opposed to "reactionary," which is how they refer to the opposition party, whose members are the political descendants of the former authoritarian regimes. Replacing "democratization" with "reform" was necessary because, after 40 plus years of use since it first appeared in 1960, "democratization" had become almost trite, as the slogan of the 2002 presidential election.

In that sense, it is possible to say that "democratization" has been the magic word for the two recent administrations. Naturally, the concept that often appears in the legitimization strategy of these two administrations' policies is "democratization." By analyzing different uses of "democracy" and the political and intellectual origins of those uses, the contradictions that exist among the various policy areas of the two most recent administrations can be understood.

\section{Political Conservatism}

Because General Park Jung Hee took power via a military coup on May 16, 1961, the political leaders from the previous administration formed one of the main political resistance groups. Yoon Bo Sun, the president during the Second Republic (1960-1961), which was demolished by Park's coup, became the leader of the opposition party.

This group of politicians was by no means progressive. The group's political lineage included descendants of the Kim Sung Soo and Ho Nam elites, who found political support from the agricultural landlord class in the Japanese colonial period of the First Republic (1948-1960). This group collaborated with the Japanese colonial government and was the governing party at the beginning of the First Republic until the alliance with President Lee broke because of his diverse attempts to monopolize power. The group's political orientation was not very different from that of President Lee, and thus Korean political scientists believe the group was forced into the democratization movement. Kim Dae-Jung and Roh Moo-Hyon, the presidents of the two most recent administrations, belong to the lineage of this conservative group. 


\section{Economic Liberalism}

Economic liberalism became an important part of the democratization movement because of President Park's strong interventionism. As is widely discussed in the literature on the developmental state, the South Korean economy under the Park Administration was characterized as a governed economy (Wade, 2004). Private companies were under the state's control through the carrot of low-interest loans and the stick of political pressure (Amsden, 1989).

Economic liberals criticized Park's system as Kwanchi Kyongje, meaning "a government-governed economy." Economic liberals fought against Kwanchi Kyongje both inside and outside the state. Inside the state, U.S.-educated bureaucrats who occupied important positions after the 1980s were the driving force. Kim Jae Ik, who was the senior secretary to the president and had the informal title of presidential economics tutor between 1980-1983, received his Ph.D. from Stanford's economics department and had worked for the Bank of Korea, Korea's central bank. His successor, Sakong Il, received his Ph.D. degree from the University of California, Los Angeles, which is sometimes mocked as the University of "Chicago" at Los Angeles, and taught finance at New York University. These were two of the earliest economic liberals in the bureaucracy, and they began dismantling Kwanchi Kyongje from the inside. While they did not go to the University of Chicago themselves, their research and experience in finance gave them an affinity for the Chicago school of economics.

In civil society, critics of government-led development advocated for a liberal market. After the state launched liberalization programs under the auspices of liberal bureaucrats, civil society and academic critics focused their attention on the chaebol system. The Park Jung Hee Administration chose some of the big firms from national champion industries. The administration gave them political loans with low-interest rates and other unorthodox incentives. Those big firms had peculiar governance. The founder and his family made important strategic decisions without holding the majority of stock, which was possible because the cross-holding of stock between companies kept the majority of stock under the founding family's control. Therefore, the other stockholders, whose stock-holding amounted in total to more than the majority, could not have their voice be reflected in the companies' strategies. Furthermore, founding families, using their dominance in the companies, often refused dividends. For those who believed in a liberal market economy in which stockholders' rights are considered supreme, the chaebol system was unacceptable.

The most influential critic of the chaebol system was the People's Solidarity for Participatory Democracy (PSPD), an NGO that touches on diverse aspects of politics and civil society. Similar tendencies are found in many schools of social scientists, including that of Byun Hyung Yoon and his former students. 
The Chaebols themselves were against some aspects of the developmental state. The Federation of Korean Industries, which is the association of chaebols and other big businesses, set up a research institute called the Centre for Free Enterprise in 1996. The aim of this center, as announced on its web page, clearly demonstrates its liberal economic ideas.

When freedom of economic activity is granted, when the attitude that we intend to depend on the intervention of the government to solve all problems is discarded, and when citizens stop demanding that the government give them this and that, Korea then will be able to have strong competitiveness (Centre for Free Enterprise).

Chaebols had been arguing for more of a free market and less of Kwanchi Kyongje since the 1970 s and finally created this research institute to represent this position. The chaebols' struggle was sometimes expressed in the form of political resistance, such as when Chong Joo-Yong, the founder of Hyun-Dae chaebol, ran for the presidency in 1992.

\section{Resistant Regionalism}

Popular support for the resistance was found in the Ho Nam region. In many ways, this support was created by Park, who discriminated against Ho Nam. As explained in Sonn (2007), in the 1970s, economic development planning was spatially uneven. Given that financial and human resources were scarce, it was probably necessary to concentrate those resources on a small number of cities and regions for faster economic growth. However, this strategy created a "cumulative causation effect," and the gap between the developed part of the country (i.e., developed cities in Yongnam and Seoul) and the undeveloped part (i.e., the rest of the country) continued to grow.

Park's strategy for spatially uneven economic development went along with political regionalism. There is no evidence that Park and the ruling elites intended to connect these concepts, but the two were realized almost simultaneously, and they reinforced each other. As Sonn (2007) explains, spatially uneven economic development obviously excludes many regions from the fruits of growth, so the state is likely to lose support from those regions. That loss has to be compensated for by stronger support from the regions that do enjoy the fruits of development. The Yongnam region increasingly supported Park starting in the early 1970s, thus he was able to continue ruling the country despite decreasing support from Ho Nam.

Against this, Ho Nam was not well-mobilized, politically. The most organized

group during Japanese colonial times was the elites from Ho Nam. These right-wing 
moderate nationalists became part of the ruling elite at the beginning of modern Korea following its liberation in 1945. However, starting in 1950, they were gradually excluded from power by President Lee, who wanted to monopolize it. By the beginning of the 1970s, they were a minority group and called "the Old Sect" within the opposition party. Moreover, they did not see themselves as regional representatives. A charismatic young leader named Kim Dae Jung emerged from the region, but he did not belong to the Old Sect. However, as a presidential candidate in the 1972 election, Park mobilized Yongnam by framing the election as a competition between Ho Nam and Yongnam. Ho Nam gradually responded by identifying itself with the opposition party. This is most likely the point when resistant regionalism began.

In 1980, resistant regionalism consolidated when the military elites who took power in 1979 violently suppressed resistance in Gwangju, the largest city in the Ho Nam region. Witnessing students and other demonstrators killed by the military assault that was ordered by the political elites from Yongnam, residents of Ho Nam confirmed that democracy equated to reinstating Ho Nam as a region on par with Yongnam. This resulted in exclusive voting for Ho Nam candidates in the subsequent elections.

Resistant regionalism finally took effect when Kim Dae Jung won the presidential election. His victory stemmed partially from there being two major conservative candidates, while Kim was the only liberal candidate. Roh Moo Hyun, the next president, continued Kim's legacy. He was a Yongnam victim of oppressive regionalism. His political base was Busan, within Yongnam, but because he was against the leaders of the region he was penalized by voters, who failed him in elections. However, from that failure arose the image of Roh as a resistant regionalist, and he gained the support of Ho Nam as a result. Combined with support from liberals within Yongnam, he won the presidential election in 2002.

\section{Localism}

In modern Korean history, localism was seldom pronounced as a separate line of ideology. Instead, it was always assumed that localization was part of democratization. This was because local autonomy was substantially relinquished under President Park. In the Second Republic, there was relatively well-institutionalized local autonomy. However, this changed after Park's capture of power in 1959. He removed all forms of local elections, abolished provincial and local councils, and appointed heads of local government. Local elections were revived only after 1991, toward the end of the authoritarian regime.

Furthermore, the majority of taxes were collected by the central government, and thus the local governments did not have enough financial resources at their disposal to carry out their own economic strategies. This did not change much even after the revival 
of local elections. Therefore, it is safe to say that the autonomy of local governments in South Korea has always been limited.

The relationship between democracy and local autonomy is not theoretically evident. On the one hand, bringing decision-making nearer to the people is democratic. On the other hand, if localities have extreme autonomy and the central government lacks sufficient resources, there will be an increasing gap between economically competitive localities and less competitive ones. Yet, in the South Korean public sphere, localization has almost always been regarded as part of democratization. This was because of President Park's centralism, which allowed no room for local autonomy.

Furthermore, based on its unbalanced growth strategy, the Park Administration invested more into developed Yongnam than into underdeveloped regions. As a result, people began to regard that central government as the creator of regional imbalance rather than its solution. Under these circumstances, it seemed natural that devolution would bring more balanced development.

The two liberal administrations, and especially the Roh Administration, put a strong emphasis on localism. Although that emphasis dwindled toward the end of the Roh administration, it is clear that he and his aids gave abundant lip service to devolution (Sonn, 2007).

\section{Political Left}

While a consensus was forming between conservatives and liberals, the leftist position weakened. This was because leftists allied with liberals in the urgency of democratization, and as a result of the relative weakness of their position, these leftists ended up being absorbed by liberal parties and political organizations. This absorption has a long history.

The Second Republic, before General Park's coup, was corrupt and incapable of either carrying out economic development or running a democracy. Therefore, with respect to the military coup, the leftists thought that even if Park's methods were undemocratic in the procedural sense, they might be a better alternative to a democratic government. Prominent leftists, including Chang Joon Ha, supported Park for this reason. Later on, however, when it became evident that Park's real intention was to hold power for a long time, leftists joined the democratization movement led by political conservatives. From the 1960 s to the 1980s, leftists were offering bipanjokjiji, or "support without agreement", to Kim Dae Jung and other political conservatives. In the 1971 and 1987 presidential elections, progressive candidates withdrew from the race to support Kim Dae Jung in defeating authoritarian leaders. It was very common for student activists with leftist leanings to volunteer to help conservative candidates in the general elections. Furthermore, many leftists joined conservative parties, partly for their individual career interests and partly for their alliance with conservative parties against the authoritarian administration. 
A similar tendency is found within academia. For example, there is Park Hyun Che's concept of Chonmin Jabonjooeu, which is based on Max Weber's concept of Pariah Capitalism. According to Weber, Pariah Capitalism is "politically and speculatively oriented adventurous capitalism", as opposed to "the rational organization of capital and labor." While the South Korean economy under Park's developmental state was similar to Pariah Capitalism in Weber's terms, the use of this concept tells us more. If the developmental state was a problem because of its similarity to Pariah Capitalism, "normal" capitalism should be the ideal form of the economy. Park Hyun Che was a socialist intellectual who participated in guerrilla warfare against the South Korean government in the 1950s. If he was loyal to socialist ideas, he would have criticized capitalism itself rather than Pariah Capitalism, but he chose to criticize the latter, and that was a symptom of the fusion of his ideas with economic liberalism. That concept was used widely among liberal and leftist social scientists in their criticism of the authoritarian regime.

\section{Theoretical Interpretation of Findings}

The state is not completely confined by either historical trajectory (weakening of the state by democratization and growth of capital, in this case) or an international context (neoliberalization and devolution). While it complies with the neoliberal process, the state attempts to preserve itself by differentiating its neoliberalization from that of its Western European counterparts. In the case of both Songdo and regional balance policy, the state finds a way to at least partly enhance its influence over localities. In Songdo's case, the national state directly manages to create a neoliberal space. In the case of regional balance policy, the state disciplines local governments, holding them responsible for the neoliberalization of their territories, but increases its financial leverage to influence the process.

Traditionally, the main objective of a national state's territorial policy has been to reduce economic and social gaps among regions. This is why political economists thought of territorial planning as a part of the state's welfare or legitimization function, rather than as a part of a production or accumulation function (O'Connor, 1973). This paper finds evidence that in South Korea, the national state was the driving force behind neoliberal spatial policies, the consequence of which is a neoliberal disciplining of localities. A more general implication of this finding is that there is no clear-cut boundary between the various functions of the state. As a result, a policy that usually belongs to the welfare function can be used as part of the growth function. This requires a noble combination of legitimization discourse and actual policy content. In the case of South Korea's regional balance policy, the state used Keynesian welfare discourse, but the actual policy contents were neoliberal. 
The findings of this paper show that the state's neoliberal spatial strategy is not homogeneous. Rather, it is differentiated according to the target locality. In Incheon's case, where attractive locational characters are located, the state directly creates a space for neoliberalism in the form of a special economic zone. This approach is similar to that of neoliberal urban policies in Western Europe. However, for less favorable localities, the state's approach has been disciplinary.

In spatially differentiated spatial planning, the construction of enclaves is an effective measure. By linking enclaves with different spatial strategies, the state can maintain its hold on the territorial economy without contradicting neoliberal ideology. In the South Korean case, the construction of enclaves can be for either the diffusion of neoliberalism or the containment of it.

A large part of regional balance policy has been environmental projects, such as the construction of an innovation city and an enterprise city in localities where neoliberalism cannot prevail. However, the purpose of the creation of these neoliberal enclaves was not to contain neoliberalism, but rather to diffuse it. In the construction of these neoliberal cities, the national state imposed conditions that had a disciplinary effect on local states.

The findings of this research show that neoliberalization is not a smooth process, even within the state. The South Korean state attempts to discipline local governments that do not necessarily have an interest in neoliberalization. From the point of view of local governments, receiving aid from the central government would be easier and more guaranteed than pursuing a neoliberal strategy, such as promoting innovation and attracting investment. However, the national government, whose main legitimization discourse is growth not welfare, is not likely to allow local governments to continually draw from resources that could be used for projects that directly benefit growth. Behind this interscalar conflict is a wider social conflict among socially and spatially divided groups of people and organizations. Those that would likely take the neoliberalizing state's side include large firms that would mostly benefit from the neoliberalization of localities. At the same time, a cross-class consensus exists in Seoul that is against state aid for other provinces.

The corollary of all this is that the state's spatial process, including but not limited to spatial neoliberalization, is not a smooth functional process that a structural understanding of state space would be able to predict. The interests of diverse social groups find their way into the process of the state, and the state itself is divided by interests between scales, among divisions, among informal groups, among others. Consequently, neoliberalization is a process of negotiation and conflicts, rather than a smooth transition to a state form that better represents class interest. The source of this resilience of the state is, at least in the South Korean case, the heterogeneity of the ruling block. 


\section{Bibliography}

Amsden, A.H. (1989). Asia's Next Giant: South Korea and Late Industrialization. Oxford: Oxford University Press.

Brenner, N. (2004). New State Spaces: Urban Governance and the Rescaling of Statehood. Oxford: Oxford University Press.

Cerny, P. (1995). Globalization and the changing logic of collective action. International Organization 49, 595-625.

Choi, M.R. (2005). Substantial budget increase in response to low birth rate and aging population. Government Press Releases. The Government of Republic of Korea. Retrieved from http://www.news.go.kr/warp/webapp/news/view?r=\&section_id=pm_sec_2\&id=ecb 2166e376056d369fcac5. (Accessed on 09 March 2006).

Giddens, A. (1990). The Consequences of Modernity. Cambridge: Polity Press. Gray, J. (1998). False Dawn: The Delusions of Global Capitalism. London: Granta.

Greider, W. (1997). One World, Ready or Not. New York: Simon \& Schuster. Hardt, M., \& Negri, A. (2000). Empire. Cambridge: Harvard University Press. Hyake, F. (1944). The Road to Serfdom. Chicago: Univesity of Chicago Proess

Jessop, B. (1992). Fordism and Post-Fordism: a critical reformulation. In Storper, M,. \& Scott, A.J. (Ed.). Pathways to Industrialization and Regional Development. (pp 42-62). London: Routledge.

Jessop, B. (2002). The Future of the Capitalist State. Cambridge: Polity Press.

Jones, M. (1999) New Institutional Spaces: TECs and the Remaking of Economic Governance. London: Routledge.

Katzenstein, Peter (1985) Small States in World Markets: Industrial Policy in Europe. Ithaca: Cornell University Press.

Kim, J. (2007). The State and the City. Gwangju: Chonnam University Press.

Lash, S., \& Urry, J. (1994). Economies of Signs and Space. London and Thousand Oaks: Sage.

Nam, D.G. (2008). White Paper of Roh Administration Vol. 6: Spatial Balance. Seoul: Government Information Agency.

O’Connor, J. (1973) Fiscal Crisis of the State, New York: St. Martin's Press.

Ong, Aihwa. (2000). Graduated sovereignty in South-East Asia. Theory, Culture \& Society, 17(4), 55-75

Park, Y.S. (2008). A man who changed the map of Korea. Hangook Kyeongje Shinmun, Seoul. 
Peck, J., \& Tickell, A. (1994). Searching for a new institutional fix: the After-Fordist crisis and the global-local disorder. In Amin, A (Ed.) Post-Fordism: A Reader. (pp 280-315). Oxford: Blackwell.

Saad-Filho., Alfredo., \& Deborah Johnston.(2005). Neoliberalism: A Critical Reader (Eds.), Pluto Press.

Shin, H. Sonn, J. \& Park, S. (forthcoming) The emergence of a multi-scalar growth regime and scalar tension: The politics of urban development in Songdo New City, South Korea. Environment and Planning $C$.

Sinclair, T. (1994). Between state and market: hegemony and institution of collective action under conditions of international capital mobility. Policy Science, 27, 447-66.

Sonn, J.W. (2007). Insulation with solidarity as a political condition for implementation of polarized development strategy: the South Korean experience and its theoretical implications. International Planning Studies, 12, 221-240.

Sonn, J.W., Shin, H. \& Park, S. (2015) Mega urban project and two competing accumulation strategies: Negotiating discourses of Songdo International City development. Paper presented in 2015 Annual Meeting of Association of American Geographers, Chicago

Strange, S. (1996). The retreat of the State: The Diffusion of Power in the World Economy. Cambridge: Cambridge University Press.

Swyngedouw, E. (1997). Neither global nor local: 'glocalization' and the politics of scale. In Cox, K. (Eds.). Spaces of globalization: reasserting the power of the local. (pp 137-166). New York: Guilford.

The Presidential Committee on Balanced National Development (PCBND). (2005). The Participatory Government's Policies for Balanced National Development - The Vision and Accomplishments.

Wade, R. (1996). Globalization and its limits: Reports of the death of the national economy are greatly exaggerated in Berger, S. and R. Dore. (Eds.) National Diversity and Global Capitalism. Cornell University Press. pp. 60-88.

Wade, R. (2004) Governing the Market, Princeton: Princeton University Press.

Weiss, L. (1998). The Myth of the Powerless State: Governing the Economy in a Global Era. Cambridge: Polity

Center for Free Enterprise. CFE`s Aim. Retrieved at http://www.cfe.org/eng3/main/index.asp?cid=160200 (Accessed on 02/04/2006).

Weiss, L. (2003). States in the Global Economy: Bringing Domestic Institutions Back In, (Eds.). Cambrdige: Cambridge University Press.

Weiss, L. (2005). The state-augmenting effects of globalisation. New Political Economy, 10(3), 345-353.

Wriston, Walter (1992). The Twilight of Sovereignty: How the Information Revolution is Transforming the World. New York: Charles Scribner \& Sons. 